Reference: Clarke, K. C. and Jeffrey J. Hemphill (2002) The Santa Barbabra Oil Spill, A Retrospective.

Yearbook of the Association of Pacific Coast Geographers, Editor Darrick Danta, University of Hawai'i Press, vol. 64, pp. 157-162.

\title{
The Santa Barbara Oil Spill: A Retrospective
}

Keith C. Clarke, Professor and Chair

Jeffrey J. Hemphill, Graduate Student

Department of Geography

University of California, Santa Barbara

Santa Barbara

CA 93106

kclarke@geog.ucsb.edu, jeff@geog.ucsb.edu

The year was 1969, a momentous year for the nation and the world. At the movie theater, Easy Rider and Butch Cassidy and the Sundance Kid were playing. A new generation converged on Yasgur's farm in New York for Woodstock. From the moon, we heard "Houston ...Tranquility Base here. The Eagle has landed." In the fall, the Amazin' Mets won the World Series, and in Vietnam, the war raged on. Early in that same year, a new attitude toward the environment was born in Santa Barbara, California. At 10:45 am on Tuesday morning, January 28,1969 , about five miles off the coast from the aptly named small coastal community of Summerland, all hell broke loose. Like most catastrophes, there was not one point of failure but many acting in concert.

The problems began on an offshore drilling rig operated by Union Oil called platform Alpha, where pipe was being extracted from a 3,500 foot deep well. The pressure difference created by the extraction of the pipe was not sufficiently compensated for by the pumping of drilling mud back down the well, which caused a disastrous pressure increase. As the pressure built up and started to strain the casing on the upper part of the well, an emergency attempt was made to cap it, but this action only succeeded in further increasing the pressure inside the well. The consequence was that under extreme pressure a burst of natural gas blew out all of the drilling mud, split the casing and caused cracks to form in the seafloor surrounding the well. A simple solution to the problem was now impossible; due to the immense pressure involved and the large volume of oil and natural gas being released a "blowout" occurred and the 1969 Santa Barbara oil spill was under way.

Figure 1: Platform A during the 1969 Santa Barbara Oil Spill. Image courtesy of the UCSB Map and Image Library. Used with Permission.

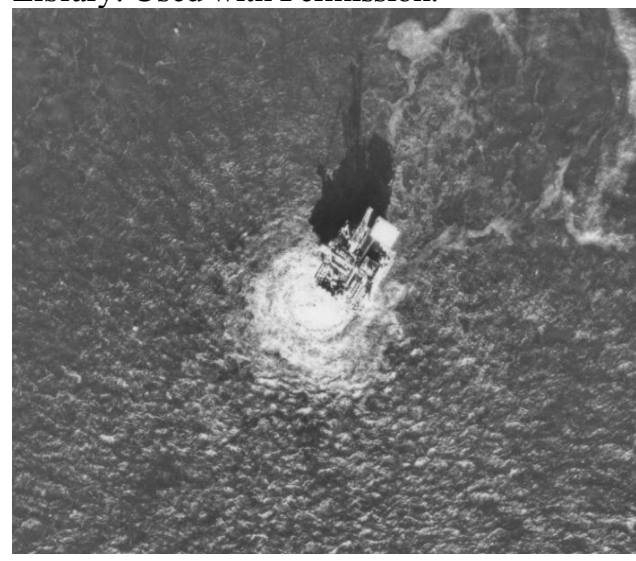


In retrospect, the simplified cause of the blowout was an industrial accident. Yet how the accident precipitated the events that followed was far from simple. Union Oil (now Unocal) had been granted a waiver by the United States Geological Survey that allowed them to use a shorter casing on the pipe than Federal Standards prescribed, a casing is a reinforcing element of the well that is supposed to prevent blowouts. Even though the well itself was capped, the fragmentation of the wellhead produced a disaster. Oil and natural gas broiled to the ocean surface in the vicinity of the oil platform for eleven days while increasingly desperate attempts were made to contain and stop the spill. The techniques, equipment and resources necessary to combat an oil spill of this magnitude did not exist at the time. On the eleventh day, chemical mud was successfully used to seal the cracks in the seafloor, but only after approximately three million gallons of oil escaped. The wind, ocean currents, tides and waves dispersed the spilled oil into the pristine and biologically diverse waters of the Santa Barbara channel and coated the shoreline.

Platform Alpha is one of several drilling rigs that extract oil from an oil rich geologic structure called the Venture Avenue Anticline that traverses the Santa Barbara Channel. There are vast quantities of oil beneath the ocean floor in the Santa Barbara Channel, in fact it was in this area where the world's first offshore drilling took place from a pier at the turn of the twentieth century. Today, as one drives from Ventura to Santa Barbara along California Highway 101, along the roadside is small seaside town called La Conchita (known for a famous landslide that occurred in 1995), it is possible to look out and see a row of active drilling platforms. This linear arrangement reflects the trajectory of the Ventura Avenue Anticline, which comes onshore at La Conchita. Along this feature sits platform Alpha. From this point, the oil spread primarily west, toward the Santa Barbara coastline. Eight hundred square miles of ocean were impacted, and 35 miles of coastline were coated with oil up to six inches thick. The oil muted the sound of the waves on the beach and the odor of petroleum was inescapable. The ecological impact was catastrophic. Rescuers counted 3,600 dead ocean feeding seabirds and a large number of poisoned seals and dolphins were removed from the shoreline. The spilled oil killed innumerable fish and intertidal invertebrates, devastated kelp forests and displaced many populations of endangered birds.

Figure 1: Air Photo of Santa Barbara Harbor taken during the clean-up. Image courtesy of the Map and Imagery Laboratory, UCSB. Used with permission.

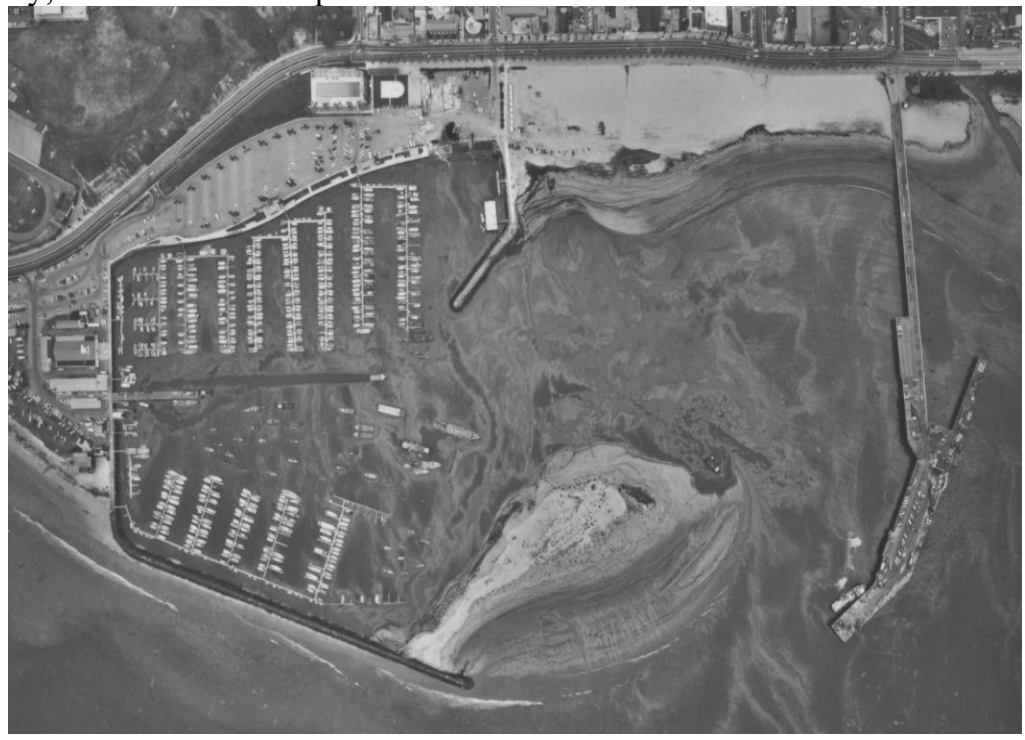


The clean-up effort began almost immediately, with significant active participation from the local community. The damage was so intense and extensive that people of all age groups and political persuasions felt compelled to help in every way they could. On the beaches, piles of straw were used to absorb oil that washed on shore, contaminated beach sand was bulldozed into piles and trucked away. Skimmer ships gathered oil from the ocean surface, and volunteers rescued and cleaned tarred seabirds at a series of hastily set-up animal rescue stations, one of which was located at the Santa Barbara zoo.

While the popular backlash against the oil companies involved grew, the public discussion that was to have long term consequences for the nation started in earnest. For example:

\section{President of Union Oil Co. Fred L. Hartley:}

"I don't like to call it a disaster, because there has been no loss of human life. I am amazed at the publicity for the loss of a few birds."

\section{Santa Barbara News Press Editor Thomas Storke:}

"Never in my long lifetime have I ever seen such an aroused populace at the grassroots level. This oil pollution has done something I have never seen before in Santa Barbara - it has united citizens of all political persuasions in a truly nonpartisan cause."

\section{President Richard Nixon:}

"It is sad that it was necessary that Santa Barbara should be the example that had to bring it to the attention of the American people... The Santa Barbara incident has frankly touched the conscience of the American people."

\section{Nature writer John McKinney:}

"I had been impressed by the way energetic college students, shopkeepers, surfers, parents with their kids, all joined the beach clean-up. I saw a Montecito society matron transporting oily birds in her Mercedes."

Into the fray came The Honorable Walter J. Hickle, the brand new United States Secretary of the Interior and, as overseer of the USGS, nominally responsible for the waiver obtained by Union Oil for the shorter casing implicated in the disaster. Hickle's story is told elsewhere, but his acceptance of responsibility was the start of a long chain of Federal concessions admitting that it was at fault to some degree. First, Secretary of the Interior Hickle, and later President Nixon, personally viewed the damage. This experience undoubtedly influenced their opinions regarding the concerns being expressed by the people of Santa Barbara who were affected by the spill and the newly emerging environmentally conscious political movement. In a White House report a full 17 years later, it was stated that:

"The federal government had largely ignored the need to protect commercial, recreational, aesthetic, and ecological values of the area.” (White House Council on Environmental Quality, 1996). With the damage caused by the oil spill the threshold had been crossed, and never again would environmental costs be seen in the same light. 
The tangible long term outcomes that were the direct result or a consequence of the oil spill included at least the following:

- A broad environmental grassroots movement was founded leading to the first, Earth Day in November of 1969. (http://earthday.envirolink.org/history.html)

- Get Oil Out (GOO) collected 100,000 signatures for a petition to ban offshore drilling

- The Environmental Defense Center was founded (http://www.rain.org/ edc/) and the first Environmental Studies program was started at UC Santa Barbara (http://www.es.ucsb.edu/general_info/about.htm).

- The California Coastal Commission was created from a statewide initiative. (http://www.coastal.ca.gov). This commission today has powerful control over human activities that impact California's coastal areas.

- The State Land Commission banned offshore drilling for 16 years, until the Reagan Administration took office.

- President Nixon signed the National Environmental Policy Act of 1969 (http://es.epa.gov/oeca/ofa/nepa.html). Leading the way to the July 1970 establishment of the Environmental Protection Agency.

- California Environmental Quality Act (CEQA) became law (http://ceres.ca.gov/ceqa).

- Federal and state regulations governing oil drilling were strengthened.

- A CIA owned U-2 Spy Plane took the first ever air photo reconnaissance images of Santa Barbara for peaceful purposes other than mapping of denied territory (Marx, 1984).

- Federal Government founded the Civil Applications Committee, aimed at coordinating intelligence and military systems for national emergencies.

Now, after 33 years, and as memories fade, the impacts of the post-spill consequences for environmental policy outweigh historically the physical impacts of the spill itself. Yet the oil industry and coastal environments remain in a state of uneasy coexistence. There are still many oil spills (37 nationally in 1994), and many of them have far exceeded that of January 1969 in magnitude and even consequences. Current politics have again placed a strain on the protected status of our wildlife refuges and even national forests, while the automobile industry has exploited pollution law loopholes to sell cars that consume more and more gasoline. In the short term, the positive consequences of conservation seem overwhelmingly obvious. In the long term, perhaps alternatives to the privately owned internal combustion engine may make the uneasy coexistence a historical footnote. As geographers, we have a special responsibility to remember the devastation caused by the Santa Barbara oil spill of 1969, and its costly lessons.

\section{Additional Information}

The images and source materials used for this paper, as well as other information concerning the oil spill, are available at the web address below.

http://www.geog.ucsb.edu/ jeff/sb 69oilspill/

\section{References}

Gary T. Marx (1984) Notes On The Discovery, Collection, And Assessment Of Hidden And Dirty Data in J. Schneider and J. Kitsuse, Studies in the Sociology of Social Problems, Ablex, 1984. (also at: http://web.mit.edu/gtmarx/www/dirty.html) 